\title{
China's “New Regionalism": Subnational Analysis in Chinese Political Economy
}

\section{Citation}

Rithmire, Meg. "China's 'New Regionalism': Subnational Analysis in Chinese Political Economy." World Politics 66, no. 1 (January 2014).

\section{Published Version}

http://dx.doi.org/10.1017/S004388711300035X

\section{Permanent link}

http://nrs.harvard.edu/urn-3:HUL.InstRepos:12748549

\section{Terms of Use}

This article was downloaded from Harvard University's DASH repository, and is made available under the terms and conditions applicable to Open Access Policy Articles, as set forth at http:// nrs.harvard.edu/urn-3:HUL.InstRepos:dash.current.terms-of-use\#OAP

\section{Share Your Story}

The Harvard community has made this article openly available.

Please share how this access benefits you. Submit a story.

Accessibility 


\title{
China's "New Regionalism": Subnational Analysis in Chinese Political Economy
}

\author{
Meg Elizabeth Rithmire ${ }^{1}$ \\ Assistant Professor \\ Harvard Business School \\ mrithmire@hbs.edu
}

Dan Breznitz and Michael Murphee. 2011. Run of the Red Queen: Government, Innovation, Globalization, and Economic Growth in China. New Haven, CT: Yale University Press, $278 \mathrm{pp}$.

Donaldson, John. 2011. Small Works: Poverty and Economic Development in Southwestern China. Ithaca, N.Y.: Cornell University Press, 221 pp.

Hurst, William. 2009. The Chinese Worker After Socialism. Cambridge: Cambridge University Press, 198 pp.

Segal, Adam. 2003. Digital Dragon: High Technology Enterprises in China. Ithaca, N.Y.: Cornell University Press, 184 pp.

Thun, Eric. 2006. Changing Lanes in China: Foreign Direct Investment, Local Governments, and Auto Sector Development. Cambridge: Cambridge University Press, $326 \mathrm{pp}$.

Whiting, Susan. 2001. Power and Wealth in Rural China: The Political Economy of Institutional Change. New York: Cambridge University Press, 348 pp.

\section{ABSTRACT:}

The study of Chinese political economy has undergone a sea change since the late 1990s; instead of debating the origins and direction of national reform, scholars have turned to examining the origins of local economic variation. This essay reviews recent work in regional political economy of contemporary China. In keeping with a movement in comparative politics toward analyzing subnational politics, the "new regionalists" seek to identify and explain meaningful heterogeneity in the Chinese polity and economy. Yet they go further than simply using subnational cases to generate or test theories about Chinese politics; instead, they propose that subnational political economies in China are a function of endogenous change rather than a reaction to national priorities. After identifying differences between "new regionalism" and previous studies of decentralization in China, I discuss this work according to the theoretical approaches (institutional, ideational, and socio-historical) used to explain the origins of regional differences. I conclude by examining the limitations of the new regionalist agenda in comparative and historical context and suggesting that scholars move past unconditional acceptance of the causal power of "socialist legacies" and instead attend to the importance of changes in the post-Mao administrative hierarchy.

\footnotetext{
${ }^{1}$ I am grateful to Rawi Abdelal, Nara Dillon, Rick Doner, Kyle Jaros, Kristen Looney, Ben Read, and especially Sebastian Heilmann for comments on various drafts. I also appreciate critical comments from some of the authors of the books under review, and especially John Donaldson.
} 


\section{Disaggregating Economies in China and Beyond}

China is not one place. Increasingly, nowhere is. Fortunately, research methods in comparative politics are catching up to ever-expanding subnational variation in the political and economic phenomena. While approaches in comparative politics have historically focused primarily on national-level variables and, therefore, comparisons across countries, more recent approaches celebrate the importance of local-level variables and outcomes and make use of cases at the sub-national level to generate and test theories. ${ }^{2}$ The subnational level of analysis has grown in importance so much recently that some scholars have identified a "subnational turn" in comparative politics. ${ }^{3}$

Such a turn has occurred in the field of Chinese politics as well. Research in the past, constrained by restricted access to the Mainland, focused on generalizing about politics in China from single case studies. ${ }^{4}$ The great diversity of sources, written and fieldwork-based, that have emerged in the past twenty years with increased access, however, has given light to extensive variation within the Chinese polity with regard to a number of political phenomena. ${ }^{5}$ Scholars have made use of this variation to generate and test hypotheses about outcomes as varied as public goods provision, ${ }^{6}$ labor relations and the rule of law, ${ }^{7}$ and state-owned enterprise (SOE) reform and restructuring. ${ }^{8}$

\footnotetext{
${ }^{2}$ On democratization and local authoritarianism, see Hagopian 1996, Cornelius, Eisenstadt and Hindley 1999, Gibson 2004. On state-building, see Ziblatt 2006. On public goods provision, see Tsai 2007. On civil war and/or ethnic conflict, see Kalyvas 2006, Varshney 2002, Wilkinson 2006.

${ }^{3}$ Ziblatt and Tsai 2009. The authors locate a number of sources of this trend: "decentralizing trends across the globe, a growing interest in politics 'on the ground' away from distant national capitals, the theoretical call to 'disaggregate' the state, as well as increased access to technological innovations such as easily accessible Geographic Information System (GIS) software that provide us with the opportunity to investigate more fine-grained spatial data" (p. 2). See also Snyder 2001.

${ }^{4}$ Chan, Madsen, Unger 1984, Walder 1986.

${ }^{5}$ Perry 1994.

${ }^{6}$ Tsai.

${ }^{7}$ Lee 2007.

${ }^{8}$ Steinfeld 1998.
} 
The transition from "national models" to subnational ones has been even more pronounced in the subfield of Chinese political economy. The debates that motivated the field in the 1990s involved the advantages and disadvantages of China's "gradualist" approach, ${ }^{9}$ whether Chinese growth was a function of gradualism or occurred in spite of it,${ }^{10}$ and whether and how the Chinese Communist Party (CCP) could preside over phenomenal economic growth without institutions, such as property rights and contract enforcement, deemed requisite for sustained prosperity. ${ }^{11}$ Observing that, thirty years after reforms began in 1978, China continues to show little likelihood of adopting the institutions of advanced industrial democracies, scholars have in the past ten years turned their attention to identifying and explaining subnational variation in economic development and reform in China. Rather than treating the Chinese economy as en route from socialism to an identifiable form of capitalism, they are instead examining how subnational differences in the organization of economic activities and the nature of market mechanisms have emerged and what implications they have for a "national" Chinese growth model. How have local governments differently interpreted and implemented national reform policies? What explains different decision-making regarding investments and growth strategies? How have different local growth strategies beget different socioeconomic consequences?

In this review essay, I take stock of six books that bring regional variation in patterns of growth, innovation, and investment to the fore in research on the political economy of reform and development in China. All of these authors, though they analyze phenomena as diverse as industrial policy, property rights, labor politics, and rural

\footnotetext{
${ }^{9}$ Naughton 1995.

${ }^{10}$ Sachs and Wing Thye 2000, Rawski 1995.

${ }^{11}$ Clarke 2003, Oi 1999, Oi and Walder 1999, Shirk 1993.
} 
poverty, take regional variation as the basis for subnational comparison and identify local - as opposed to national-level political factors as key independent variables. In this sense, they are not only interested in variation in economic outcomes, but variation in local economic orders, or the very logic of economic decision-making and patterns of behavior. ${ }^{12}$ Importantly, these authors do not treat all subnational units as equal or even similar; instead, they emphasize fundamental differences in regional political arrangements, economic institutions, and relations to the center. They differ, however, in their assessments of the causal power of institutional arrangements, political and social histories, and locally held norms and ideas about the economy in the origins and reproduction of regional differences. I first examine this recent work in light of studies of "decentralization" in China and beyond, and then discuss models of regional difference according to what kinds of local level factors the various authors emphasize. The last section critically examines this growing research agenda. I first identify conceptual and theoretical limitations of this "new regionalism" in light of research in comparative political economy and the Chinese historical tradition and conclude by critically discussing the causal power of "socialist legacies" and suggesting ways in which changes to the post-Mao political hierarchy may explain critical differences among regions. ${ }^{13}$

\footnotetext{
${ }^{12}$ I borrow the term "economic order" from Gary Herrigel's (1996) book on regional economic orders in Germany, discussed below. Herrigel uses "order" rather than, say, "industrial organization" or "industrial structure" to signal the use of a "broader lens to analyze economic practice" (pp. 22-3). This "broader lens" certainly describes the books under review here.

${ }^{13}$ This essay does not review empirical work on the growing regional disparities and regional inequalities that mark the Chinese political economic landscape. These inequalities are the subject of a large literature, produced mostly by geographers, economists, and policy analysts, which mostly debates whether these inequalities in wealth, growth, social welfare, and investment, are a "natural" stage of economic growth and will disappear in due time or they are direct products of China's spatially differentiated growth policies. The books under review here, all by political scientists, are not about whether economic indicators and outcomes vary across China - an empirical reality that they would certainly accept as given — but instead about how the fundamental rules of governing the economy differ. For the geographer's perspective, see Fan 1995, Fan 1997, Wang and Hu 1999. For economists on regional inequality, see introductory chapter
} 


\section{Beyond Decentralization: Local Politics as Subject}

The division of authority between different levels of government has loomed large in accounts of the course of Chinese reforms and the growth miracle. The central puzzles have been 1) the role of political and fiscal decentralization in China's economic reforms and the CCP's political resilience, and 2) how to understand the limits of local autonomy and, relatedly, the limits of central authority.

Those that attribute China's political resilience and economic success to political and fiscal decentralization make a number of arguments about the importance of local autonomy over economic decisions: local autonomy guards against potential incursions of central authorities, generates fiscal incentives for local officials to pursue growth and restructure the state-owned economy, and encourages local reform experiments. ${ }^{14}$ In this view, China's reforms, and therefore its explosive economic growth, have been "bottomup," stimulated at the local level: "Experimentation, learning, and adaptation all follow from the inception of local political freedom over the economy." ${ }^{\prime 15}$ Another strain of scholarship instead emphasizes the role of strong central control over diverse subnational actors as both a driver of reform and a reason why the CCP has maintained political control in the face of economic change. These scholars do not dispute that the Chinese system is politically and fiscally decentralized in important ways, but they contest the idea that decentralization can explain economic success and instead focus on the ways in

by Shue and Wong and chapters by Wong and Riskin in Shue and Wong 2007, Fan, Kanbur and Zhang 2009, Wong 1997. On the policy side, see UNDP, World Bank, and CCP White Paper on Inequality 2001.

${ }^{14}$ For a thorough - and critical-review of these arguments, see Cai and Treisman 2006.

${ }^{15}$ Montinola, Qian and Weingast 1995, 78. See also Lau, Qian and Roland 2000. 
which Beijing retains firm control over subnational actors. ${ }^{16}$ In this view, the directionality of innovation and reforms is "top-down;" policy directions are set at the “commanding heights" in Beijing, and subnational actors vie for promotion within a hierarchical party-state by meeting those objectives or attaching themselves to one elite faction. $^{17}$

The authors of books under review here- to whom I'll refer as the "new regionalists" - depart from this debate in two important ways. First, instead of staking a claim in the importance of local versus central authority in Chinese political institutions, these authors emphasize the causal power of the system's endemic uncertainty and underinstitutionalization. Envisioning the Chinese political system as something akin to federalism, in their view, is a misreading of the relationship between levels of the Chinese state. Local officials are not reacting to clear direction and identifiable incentives embedded in China's political institutions, but rather making do with the resources they have in a climate of ambiguity. ${ }^{18}$ Adam Segal (2003) and Dan Breznitz \& Michael Murphree (2011) make this argument most explicitly. Segal explains that national uncertainty about the meaning of minying enterprises - "people run," clearly not stateowned but not necessarily private-led different localities to interpret the new category of ownership in different ways (pp. 39-42). These varying levels of state intervention based on those interpretations created different regional political economies in the information technology (IT) sector. Breznitz \& Murphree go even further, characterizing

\footnotetext{
${ }^{16}$ See Edin 2003, Landry 2008.

${ }^{17}$ Cai and Treisman (2006) make this case most explicitly. They argue that what looks to others to be "bottom-up" experimentation and policy innovation is in fact "competition at the center between rival factions, with different ideological predispositions and local connections" (p. 507). This account is similar to one offered by Victor Shih (2008) to explain inflationary cycles and fiscal policy.

${ }^{18}$ This way of thinking of the power of uncertainty is somewhat similar to the constructivist account of decision-making, though, save Segal, these authors do not refer to the constructivist literature.
} 
the key element of the Chinese political system to be "structured uncertainty," which they define as "a part of the institutional system, although a part that prevents its 'institutionalization' by ensuring that instead of patterns of behavior becoming routinized, a multiplicity of behaviors can be followed on a specific subject without any of the actors knowing in advance which behaviors are appropriate" (p. 12). ${ }^{20}$ Critically, this uncertainty and ambiguity is not at all a product of reform-era decentralization, but rather is a continuation of a distinctly Chinese political tradition that values a lack of institutionalization and bureaucratic routinization. Other scholars, such as Sebastian Heilmann, Elizabeth Perry, and the contributors to their edited volume, Mao's Invisible Hand, have located the origins of this practice in China's revolutionary tradition, highlighting the ways in which contemporary policy-making through experimentation has its roots in the early days of the Chinese Communist Party's revolutionary bases before 1949: “China's revolution gave rise to a 'guerilla-style policy-making' approach that proved capable of generating an array of creative - productive as well as evasive - tactics for managing sudden change and uncertainty."21 "Structured uncertainty," then, is an intentional element of the broader Chinese political system, and local governments work within their own resources and constraints to formulate local policy without a clear understanding of what actions are and are not permitted. ${ }^{22}$

The new regionalists depart from previous research on the reforms in a second significant way: instead of using local realities to shed light on how China's national political and economic system works, they are examining how local level variables

\footnotetext{
${ }^{20}$ For a similar interpretation of how local actors (state and non-state) pushed the boundaries of permissibility with informal finance, see Tsai 2002.

${ }^{21}$ Heilmann and Perry 2011, p. 7. See also Heilmann 2008a, Heilmann 2008b.

${ }^{22}$ Heilmann and Perry refer to "local government on a shoestring" to describe how "localities are generally left to fend for themselves, receiving only erratic and episodic central support" (p. 14).
} 
determine different local economic realities. These scholars are not using localities as cases to illustrate the importance of a single variable or even a single causal process, but rather argue that a great deal of economic and political change might best be thought of as endogenous to local units, a product of local realities rather than simply different reactions to national priorities. In this sense, the new regionalism possesses a different ontology from previous work in Chinese political economy in that it rejects any concept of local governments or subnational units as homogenous. ${ }^{23}$ Of course, the previous generation of scholarship does not claim that these units are actually "homogenous," but theories that emphasize inter-jurisdictional competition ${ }^{24}$ or competition for promotion in a hierarchical party-state assume that local actors in China are responding the same incentives and constraints in formulating policy.

New regionalist scholars would reject the idea that one province or city can easily redirect to adopt the tactic of another. Thun puts it strongly: "Local governments are not utility-maximizing unitary actors that simply respond to the incentives created by a central government, they are political jurisdictions that have long political and economic histories and distinct institutional structures" (p. 17). Segal is also explicit that he is not testing hypotheses about national level political and economic relationships, but focusing on "local institutions, local constraints, and local politics": "The point is not simply that looking at regional economies provides a level of detail and nuance not available in studies focusing on national economies. Rather the lack of uniformity at the regional level in many economies makes local-level analysis a necessity" (pp. 164-165). To be sure, none of these authors is inattentive to decisions and preferences at the central level;

\footnotetext{
${ }^{23}$ This point is inspired by Ziblatt and Tsai's account of what they call "classic subnational analysis. Ziblatt and Tsai.

${ }^{24}$ Montinola, Qian and Weingast.
} 
central-local relations serve as key independent variables explaining subnational divergence in Donaldson's, Thun's, and Hurst's formulations, and central policy toward the IT industry sets the stage for local interpretation in books by Segal and Breznitz \& Murphree. As Hurst puts it, "The nature and behavior of the central state still matter, but the main action is at the subnational level and the most fruitful research is at this lower level of analysis" (pp. 4-5).

\section{I I . Sources of Variation: Institutions, Ideas, and History in the New Regionalism}

Scholars working in a "new regionalist" framework share an acceptance of the power of uncertainty in China, an ontology that celebrates local heterogeneity and endogenous change, and a view that not just economic outcomes but the more fundamental rules of state-economy relations differ regionally in China. If the "new regionalists" share these important notions, they do not necessarily agree on what the appropriate subnational unit of analysis and comparison ought be, or what variables or processes are most relevant in determining differences. In this section, I discuss the dominant theoretical models explaining the sources of regional political economic differences.

\section{Institutions}

One emergent theme in the new regionalism is the importance of local level government institutions in explaining divergent patterns of investment and intervention in Chinese political economy. Drawing on the "historical institutionalism" tradition in 
comparative politics, this work emphasizes how local institutional differences have emerged and gained in importance during the reform period. ${ }^{28}$ Books by Susan Whiting (2000) and Eric Thun (2006) particularly emphasize path-dependence in local institutional development, meaning that institutions develop in ways that give rise to positive feedback and institutional complementarities, which further entrench the original institutional developments. The differences, therefore, become durable and somewhat sclerotic over time. Yet both authors take care not to neglect the power of Beijing, instead theorizing how institutions at different levels of the Chinese state interact.

Although scholars had predicted the emergence of localism in rural China at the onset of the reforms, ${ }^{29}$ Susan Whiting (2000) was among the first political scientists to thoroughly document and explain subnational variation in the post-reform countryside. ${ }^{30}$ Her puzzle began with diversity in emergent forms of property rights in rural industry: given claims of homogenization during the Maoist period, how do we account for regional patterns of industrial ownership? Her cases are counties in the mid-coastal region in the provinces of Shanghai, Jiangsu, and Zhejiang, where she observes that some county governments support primarily public (collective) rural industrial ownership (Town and Village Enterprises, TVEs) while others host predominantly privately-owned rural enterprises. The explanation she gives emphasizes the role of institutions and institutional change.

In her formulation, different rural governments supported different forms of property rights because they possessed different resource endowments and constraints

\footnotetext{
${ }^{28}$ Pierson 2000, Thelen 2003.

${ }^{29}$ Shue 1988.

${ }^{30}$ See also Chŏng 2000. Chung's book was one of the first to examine local variation in decentralization, reacting to research that emphasized the power of farmers' (perhaps unorganized) movements and the central state and elided the importance of local government. See Kelliher 1992, Zhou 1996.
} 
inherited from the Maoist period. Specifically, some counties inherited strong collective enterprises from Mao era rural industrialization while others were forced to rely on the strength of private initiatives. ${ }^{31}$ Property rights in rural industry then shaped the development of different extractive institutions: officials in townships with collective enterprises had incentives to collude with those enterprises to evade taxes, and townships with private enterprises innovated different ways to resolve information problems and lower costs of collecting taxes from the sector. These "institutional complementarities" between forms of property rights and extractive practices are mutually reinforcing, creating "apparent path-dependence in the trajectories of rural industrial development in each region" (Whiting, 3). These claims are based on extensive documentary analysis of county fiscal and industrial histories, a product of unique access achieved by a skilled field researcher.

Eric Thun (2006) makes a similar argument to Whiting's regarding the importance of institutional variation but focuses on relationships between local politics, foreign direct investment, and the automobile industry. His motivating question is how "two decades of reform have prepared state-owned Chinese auto firms for the challenge of globalization," a challenge he breaks down by examining how Chinese firms use FDI in the context of local level institutions (p. 7). He tracks how different localities (Shanghai, Guangzhou, Beijing, Changchun, and Wuhan) differently structure the local institutions that govern the auto industry. Theorizing that they interact with the form of

\footnotetext{
${ }^{31}$ I take up a more thorough discussion of the Maoist period in a section on socialist legacies below.
} 
local inter-firm relations, he finds that some local institutional environments are superior to others in achieving success in the auto sector. ${ }^{34}$

The institutions in Thun's model are both the internal structure of local bureaucracies and central-local relations. The ways in which local governments organize the bureaucratic agencies that deal with the auto industry and the degree of fragmentation determine the kind and degree of local state intervention in the economy. The Shanghai municipal government successfully established a new office in charge of localizing supply for the industry and coordinating oversight and investment; Beijing and Guangzhou did not. Perhaps surprisingly, Thun credits both cities' relationships with the center in inhibiting effective investment: in the case of Guangzhou, distance from the center presented too many alternatives to the auto industry (pp. 156-159), and in the case of Beijing, closeness to the center made local officials prioritize the country over the municipality (pp. 164-165). Central-local relations also inhibited localization of firm successes in Wuhan and Changchun because of central ownership of SOEs and "limited maneuvering ability of local actors" (p. 176). Therefore while local level institutions vary in important ways, these differences are in part a product of central-local relations. ${ }^{38}$

Dan Breznitz \& Michael Murphree (2011), writing about what they call different regional innovation systems in the Information Technology (IT) industry, also discuss "institutions," but in a way altogether different from varying local bureaucratic structures. Emphasizing the role of "structural uncertainty" and conservative central institutions,

\footnotetext{
${ }^{34}$ Thun measures "success" in two ways. First, the market share captured by any given firm. In 2002, the Shanghai firm had $32 \%$ of the domestic sedan market, while the Wuhan and Changchun firms had $25 \%$ and $10 \%$ respectively. Shanghai, however, has been the more successful story because it succeeded in promoting local suppliers for the joint-venture, and therefore translating firm success into growth for the local economy. See p. 61.

${ }^{38}$ Thun's book includes a critique of the "decentralization-experimentation" literature, which he argues neglects both local realities and the power of Beijing (pp. 15-18).
} 
they posit that China is separated into "a series of regional economic fiefdoms" in which "each region develops a unique set of capacities," the sum of which "enables China to dominate at many stages of the fragmented global economy yet inhibits business and entrepreneurs from engaging in cutting-edge, and highly risky, novel technology and products development" (p. 21). Regional diversity, for them, is less about the reemergence of pre-reform differences than it is about how competition among regions produces specialization and, as a result, diversifies the national portfolio of economic strengths in China. They are less than precise about why the Pearl River Delta (PRD) and Shanghai look different, referring to the causal power of "politics" without specifying how local politics may really differ. ${ }^{40}$ They do make mention of factors such as Maoist legacies of economic organization, the timing and sequencing of FDI and market freedoms, and localities' relationships with the central government, but lack a theoretical explanation for how those factors affect patterns of state investment and intervention and which factors matter more than others. The book's innovation is the argument that China's overall economic innovation strategy — production-stage rather than product innovation - is sustainable because regions within China are establishing something that looks like comparative advantages in different stages of the manufacturing process: "the diverse regional strengths of China ensure that even if one of its regional systems suffers a downturn, China as a whole will continue to flourish" (p. 19). While this may be true, without a more systematic understanding of why some regions adopt the "regional innovation systems" they do, the book reads more as a description of differences among

\footnotetext{
${ }^{40}$ They write, for example, "We argue that the Chinese development trajectory is the direct result of politics...specifically, political action that transferred the main loci of reforms from the center to the regions" (p. 11).
} 
Beijing, Shanghai, and the PRD in particular, rather than an explanation of how differences emerge.

\section{Ideas}

The importance attached to institutional sources of regional variation does not exclude an understanding of how ideational or cultural variables are also at play. ${ }^{41}$ Adam Segal, in his (2003) book on variation in patterns of investment and business-government relations in the IT industry, marries the two approaches: "the constraints on policymakers are both material and ideational" (p. 48). Segal finds that the same institutional arrangements that proved ineffective in fostering growth in the auto industry were quite effective in the IT industry. ${ }^{42}$ In Beijing, the local government provided guidance to entrepreneurs while still allowing them sufficient autonomy, while in Shanghai and Xi'an the local governments provided support for the sector (in the form of investment, loans, coordinating of FDI), but meddled injuriously in internal enterprise management. In Guangzhou, the local government neither aided nor impeded the IT sector (p. 16).

For Segal, local institutional patterns are remnants of the socialist period, ${ }^{43}$ but their effect is critically linked to developmental outcomes through the intervening variable of local culture:

[local officials] also relied on traditional ideas about how to organize economic activity. These beliefs were widely shared among and provided guidance to local

\footnotetext{
${ }^{41}$ For examples of a constructivist approach in comparative political economy and international political economy literature outside of China, see Abdelal, Blyth and Parsons 2010, Hall 1986, Herrera 2005, Abdelal 2001.

42 The importance of "fit" or "mismatch" between local institutions and specific sectors is the subject of an article by Segal and Thun combining their findings on the IT and auto industries. Segal and Thun 2001.

${ }^{43}$ His approach also emphasizes path-dependence: "Even when government officials have the desire and political support to build new institutions, they often find their range of policy options narrowed by past institutional arrangements. The future cannot be made independent of the past” (p. 25).
} 
officials on how enterprises should be organized, how enterprises should relate to each other, and how they should interact with the local government. (p. 5)

An example of ideas at work comes from Segal's study of the ways in which officials in Shanghai conceptualized the task of investment in the Science and Technology system. Even after decentralization, Segal says that, in Shanghai, "[t]he methods of central planning were internalized and reproduced" as the local government took the lead in a strategy of "high input, high risk, and a high level of reliance on government guidance" (p. 92). It was not necessarily structural or institutional conditions that precipitated this strategy, but instead that Shanghai economic planners were simply doing as they had always done when they decided to promote the IT industry.

John Donaldson's (2011) book on rural poverty alleviation emphasizes the power of ideas in an altogether different way: through the intervening variable of leadership. $\mathrm{He}$ investigates the relationships between state-market relations, economic growth, and poverty alleviation through a paired comparison of two provinces in Southwest China that constitute "exceptions to the correlation" between growth and poverty reduction; Yunnan province has grown at a fast pace while absolute poverty has increased, and Guizhou province has experienced dramatic reductions in the poverty rate while growth has been relatively sluggish (p. 3). The choice of cases-neighboring provinces that share common political histories, large minority populations, and similar geographies—allows Donaldson to tease out the effects of differential provincial development strategies on the poorest of residents. The argument he develops privileges the importance of four factors in reducing rural poverty, each of which is presented in a separate chapter: road construction, migration, tourism policies, and coal mining. In general, authorities in Yunnan province implemented development strategies that primarily benefited cities, 
targeted GDP growth, and encouraged large-scale industries, while their counterparts in Guizhou focused explicitly on poverty reduction, encouraging industries and projects that did not dramatically increase GDP but in which poor people could participate directly. ${ }^{46}$

But why did Guizhou and Yunnan diverge? Donaldson locates the answer in the personal experiences and ideas of provincial leaders. He considers three key potential factors that work together in varying degrees of importance: central government influence, initial characteristics of provinces, and attributes of individual provincial leaders. ${ }^{47} \mathrm{He}$ carefully considers the advice of central leaders to the two provinces, but rules out that explanation based on timing. He does find evidence that constraints from the center, in the form of central dependence on large tobacco industries and international trade and therefore interference in Yunnan, partly explain why Guizhou seemed freer to implement policies that generated little growth but did benefit the poor. Instead of emphasizing competition for promotion, Donaldson attributes different choices in policy targets chiefly to the idiosyncratic backgrounds of provincial leaders. Guizhou's leaders had ties to the province's poorest counties and "were motivated by specific ideas about how rural poverty should be addressed and by a nuanced multidimensional view of how to measure economic success that transcended simple measures of GDP." In contrast, the highest officials in Yunnan were either originally from or had served at length in the wealthiest parts of the province and were "more interested in implementing growthoriented policies that promoted industries that benefitted their home areas" (p. 56). These individually-held ideas - different from local norms and cultures of the kind Segal discusses - explain initial divergence in policy in these two provinces, after which path-

\footnotetext{
${ }^{46}$ Donaldson provides an excellent summary of these approaches in the introductory and concluding chapters. I discuss his local state models in greater detail in Section IV.

${ }^{47}$ See also Donaldson 2009.
} 
dependence sets in: “once a particular course was set and had received central support, a form of path-dependency caused the strategy to continue even after the original leaders had departed" (p. 37).

\section{Social and Political History}

Explaining regional variation in terms of different histories of political and social integration into the larger nation is perhaps the most classic form of subnational analysis in comparative politics. Research on phenomena as varied as party systems, statebuilding, and regimes has taken social processes of integration as formative "critical junctures" that hold long term consequences for the ways in which nation-states are organized. ${ }^{50}$ Many scholars have taken this kind of analysis to the subnational level, arguing that subnational patterns of state-society relations remain durable even during periods of change at the national level. ${ }^{51}$ William Hurst, in his (2009) book on the politics of laid-off workers, foregrounds the legacies of industrialization and state-society relations as key sources of regional difference. The book is organized into chapters based on the outcomes he aims to explain: pattern of layoffs, state response, re-employment, and worker contention. The key explanatory variable is the form of "working class society," produced by differential processes of industrialization and working class formation.

Hurst's model features four regions: the Northeast, North-Central China, upper Changjiang, and the Central Coast. The Northeast was settled by migrants who identified primarily with the enterprise and therefore embraced political activism as members of a

\footnotetext{
${ }^{50}$ Lipset and Rokkan 1967, Moore 1966, Ziblatt.

${ }^{51}$ This approach is most epitomized by work by Rick Locke and Gary Herrigel, which I discuss below. In addition, see Hagopian.
} 
working class. The tradition of labor activism in the Central Coast region, centered mostly in the cities of Shanghai and Tianjin, has been nationalistic and radical, positioning a domestic workforce against foreign owner-managers. The North-Central region was industrialized and "proletarianized" after 1949 by smaller state firms. Small firms meant that workers were never as closely identified with the enterprise, and worker activism has never been as strong in this region. The Upper Changiiang experienced industrialization in the 1930s and 1940s and again in the period of the "Third Front." Social life there is more rooted in the enterprise than even the Northeast, especially when firms were located in remote and mountainous areas and settled by transplants. His research sites (Benxi city in Liaoning; Shanghai; Chongqing; and Datong and Luoyang) are chosen based on their representativeness of these regions.

Hurst's "historical-social" approach aims to be more comprehensive in viewing sources of regional variation and is certainly the most ambitious in its aim to "divide China into meaningful subnational units. ${ }^{, 52}$ On the other hand, the sheer number of variables that Hurst identifies - in addition to the tripartite "working class society" variable ${ }^{53}$ he sees local state capacity, the general business environment for SOEs, market opportunities for alternative employment, and central-local relations as key "dimensions of contemporary regional political economy" (p. 26-27)—complicates any easy extraction of a causal theory from the book. On the other hand, the empirical nuance

\footnotetext{
${ }^{52}$ Hurst p. 16: "While regional analysis is not unknown in the study of China, the particular type of subnational analysis employed here has not been widely used by China scholars. Specifically, I first seek to divide China into meaningful subnational units. This is a step that previous scholarship has often paid insufficient attention to." He cities C.K. Lee's book on labor activism and the law in China, which analyzes "rust-belt" versus "sub-belt" patterns of organization and state-society relations. These are not regions in literal space, but rather represent the different politics of laid-off and migrant labor. Lee 2007.

${ }^{53}$ Hurst defines "working class society" as "a three-dimensional concept encompassing class identity (i.e. workers' view of themselves as members of a working class), the structure of works' social ties, and popular perceptions of the Maoist past" (p. 27).
} 
and richness provided by Hurst's extensive fieldwork make the book both a vivid read and an important record of labor politics at a critical moment in Chinese political history. The complex relationship between the party-state and its erstwhile proletariat does not, as Hurst reveals, lend itself to parsimonious description.

\section{Limitations and Opportunities of the New Regionalism}

Having described the new regionalism and some of its contributions, in this section I discuss its limitations and suggest fruitful paths for future research. First, I discuss the "new" regionalism in light of the "old regionalism," or literatures in both comparative political economy and Chinese history that have influenced the books under review here. Compared with comparative and historical approaches to regional political economy, contemporary research lacks the kind of methodological and conceptual clarity that would propel this research agenda forward and allow application to more general economic phenomena. Lastly, I probe how the new regionalism thus far has suffered from excessive emphasis on the causal power of socialist legacies, and discuss opportunities to explore both the power of post-Mao administrative changes and centrallocal dynamics.

\section{Regional Political Economies in Comparative and Historical Perspective}

"The Italian economy should be viewed not as a coherent national system but rather as an incoherent composite of diverse subnational patterns that coexist (often uneasily) within the same national territory." 55

\footnotetext{
${ }^{55}$ Locke 1995, 3.
} 
The above quote, which is reproduced or paraphrased in books by Segal (p. 8), Hurst (p. 6), and Thun (p. 14), comes from Richard Locke's seminal book on the importance of the region in Italian political economy. Locke's puzzle began with simultaneous characterizations of the Italian economy as experiencing "entrepreneurial dynamism" and "industrial decline" during economic adjustment efforts in the 1970s and 1980s. The book takes on both a "national models" school, which would prescribe overhauling Italy's national institutions to make them more efficient, and an "evolutionist" vision of Italian economic change, which would predict that all regions of Italy will eventually adopt the practices of successful industrial clusters. Instead, Locke discovers enduring local economic orders that differ in the structure of intergroup relations, patterns of associationalism, and links to the national center. These differences "shaped the alternative conceptions and strategies of local economic actors," explaining why firms in different regions reacted to and weathered industrial adjustment very differently (p. 21).

But Locke argues that these local economic orders have survived far more than the attempts at national industrial policy formation and efforts to re-launch economic planning. He locates the origins of these different regional economic orders in the legacy of "Italy's uneven political and economic development in which different areas were industrialized and enfranchised at different times" (p. 23). His focus, then, is on how regional orders are reproduced — and, conversely, efforts at reform or standardization are resisted - through "micropolitical" (i.e., agentic, rather than structurally determined) actions filtered through local sociopolitical networks. He documents how economic 
behavior on the part of firms, unions, management, and workers, within the same industries (automobiles and textiles) in response to similar challenges, differed by region.

Gary Herrigel, in a book published just a year after Locke's, similarly challenges "whole nation bias" in his account of industrialization and industrial orders in Germany. Questioning the classic Gerschenkronian account of Germany as the paradigmatic case of "late industrialization," Herrigel argues that only part of the German economy can be accurately characterized as "highly centralized, large-firm dominated, ultimately neocorporatist," and instead that "two distinct, parallel, and internationally competitive systems of industrial organization and practice, located in different regions, have characterized the German experience at all levels of the economy and society since the very onset of industrialization." ${ }^{56}$ The book tracks how two "industrial orders" in Germany, one which fits the Gerschenkronian characterization and the other which Herrigel calls "decentralized," originated and functioned during the period of German industrialization before World War II and were reconstituted and governed in the postwar period of growth. ${ }^{57}$ Like Locke, Herrigel locates the origins of these regional orders in divergent processes of industrialization: the decentralized order emerged from what was a smallholder property system with a "preindustrial infrastructure of craft skills," and the autarkic system emerged from late industrialization. ${ }^{58}$

The mere discovery of heterogeneity in Italy and Germany was not the major contribution of either of these books. ${ }^{59}$ These books are important in comparative

\footnotetext{
${ }^{56}$ Herrigel 1996, 1. The term "whole nation bias" originally from Rokkan 1970.

${ }^{57}$ Herrigel also writes two chapters, one on the period $1871-1945$ and one on the period $1945-1994$, on how these different orders were accommodated in national governance institutions.

${ }^{58}$ Herrigel 1996, 20.

${ }^{59}$ Scholars of Italian politics and political economy had homed in on the divergence between Northern and Southern Italy for quite some time. Robert Putnam's seminal book on social capital and differences in
} 
political economy — and formative for scholars working in subnational political economy — because of the explanations offered for how regional differences originate and are reproduced, especially during periods of economic change and industrial adjustment. It is revealing that both Locke and Herrigel take a decidedly constructivist tack in explaining how different regional political economies work and are reproduced. In light of the literature to which these authors were responding, this is not altogether surprising. Both were self-consciously reacting to "national models" schools that looked for institutional differences across nation-states and then "often assumes that certain national systems with particular organizational features are more 'mature' and/or 'efficient' than others and prescribes the active diffusion or replication of these "best (institutional) practices' across nations. ${ }^{, 60}$ Instead, both attach causal importance to the ways in which agents "on the ground," embedded in social and political networks, conceive of problems and formulate strategies than to the fixed power of "background conditions, constraints, and structures of an environment." ${ }^{, 61}$ Regional economic orders endure, then, because of the ways in which they condition and habituate local actors to make decisions rather than because of the enduring presence of specific institutional arrangements or structural conditions.

If the political science intellectual forbears of the "new regionalism" are decidedly constructivist, the dominant understanding of subnational economic activity in China is unmistakably structural. The anthropologist G. William Skinner first brought the

political organization between South and North was published two years prior to Locke's book. Putnam, Leonardi and Nanetti 1993.

${ }^{60}$ Locke 1995, 13. Locke cites work in the "institutionalist" tradition here (i.e. Hall 1986, Garrett and Lange 1986, Zysman 1983.) as well as a more constructivist tradition (i.e. Katzenstein 1978.) See Locke 1995, 13 fn. 15.

${ }^{61}$ Herrigel 1996, 23. 
question "how do we ascertain the territorial extent of an economic system?" to the fore in research on Chinese economic and political history. Skinner began his investigation into the spatial and temporal patterning of Chinese economic, social, and political life at the level of "marketing systems," territories larger than the village that formed the basis for social and economic interactions and behavior in rural China. Skinner sought to displace the village and the political administrative unit as the units of analysis of rural life, and instead implored researchers to let "the data themselves tell us," by which he meant "patterning in the flows of goods and services, money and credit, and the like." From the lowest level of granulation — the standard marketing system—Skinner moved his reevaluation of the spatial patterning of Chinese history to the regional level. $\mathrm{He}$ hypothesized that China consisted of nine "macroregions," differentiated by physiographic features, in which distinctive patterns of economic interaction emerged: "To consider units that cover only part of a macroregion is to wrench out of context a more or less arbitrary portion of a systemic whole." ${ }^{, 63}$

Though Skinner's work encountered no small amount of conceptual and empirical criticism, few would disagree that the "macroregion" approach to Chinese history constituted a paradigm shift. ${ }^{64}$ Regardless of whether one accepts or rejects Skinner's characterization of regions or claims about their role in Chinese history, as a theory of regional economic variation, Skinner's "macroregionalism" has much to recommend it. First, Skinner's theory is exceedingly clear, perhaps at the risk of oversimplifying withinregion variation, about what constitutes a "region" and its boundaries. Macroregions are delimited by drainage basins of major rivers and consist of local place hierarchies, and

\footnotetext{
${ }^{62}$ Skinner 1985, 287-8.

${ }^{63}$ Skinner and Baker 1977, 217.

${ }^{64}$ For a thorough and critical discussion of the "macroregion" as paradigm, see Cartier 2002.
} 
the patterning of economic and social activity becomes sparser as one approaches a regional boundary. ${ }^{65}$ Second, Skinner's theory consists of propositions both for how regional economies originate (physiographic differences) and how they endure over time. In fact, Skinner argued that once Chinese history is viewed in appropriate spatial terms, systematic temporal patterns become discernable as well. ${ }^{66}$ Macroregional socioeconomies were reproduced not only during natural disasters and periods of population growth and decline (the effects of which were limited by macroregional boundaries). Perhaps ironically, imperial level decisions themselves served to reproduce regional limits. Skinner details how, for example, developments such as the movement of imperial capitals or regional trade monopolies (e.g. in Canton in 1757) ignited cycles of rise and decline in various regions. ${ }^{67}$

With the exception of Segal, Donaldson, and Hurst, who cite Skinner's work, none of the authors of the "new regionalism" deal seriously with the "old" version of Chinese political and economic regions. ${ }^{68}$ In some ways, leaving the old regionalism out of the new regionalism makes sense. These scholars are all political scientists focused on state intervention in the economy and to whom a deterministic theory of physiographic regions would not likely appeal. Moreover, Skinner's theory - and the data he culled to test it — were decidedly pre-industrial. For Locke and Herrigel, the process of industrialization itself created different regions. The new regionalists, interested in industrial and post-industrial issues such as labor politics, innovation, and sector specific

\footnotetext{
${ }^{65}$ Skinner and Baker.

${ }^{66}$ Ibid.: 11.

${ }^{67}$ Ibid.: 217-219.

${ }^{68}$ Segal (p. 9) and Hurst (p. 7) cite Skinner briefly as a forerunner of their arguments about regional diversity, while Donaldson cites Skinner's substantive perspective on market towns.
} 
adjustment, would not have much use for studies of the spatial patterning of pre-industrial life.

It is in the methodological and conceptual senses that the new regionalists could borrow effectively from both the old. First, although all of the books discussed here use the term "region" in some way, the authors could be much more explicit about the characterization and scale of a "region" with respect to the outcomes they are explaining. ${ }^{69}$ Thun and Segal are dealing exclusively with urban governments: Shanghai, Beijing, Guangzhou, Changchun, and Wuhan for Thun, and Beijing, Shanghai, Xi'an, and Guangzhou for Segal. Some of these cities enjoy provincial status (meaning that they are governed directly by the center rather than by an additional provincial structure), and these administrative hierarchies feature prominently in how Thun and Segal explain variation among the cities. ${ }^{70}$ Yet Thun and Segal write about "local officials" in these cities as if they are comparable to, say, the county and township level "local officials" in Whiting's work. While the more generic focus puts their work in dialogue with earlier work on "local states," curious.

Donaldson invokes provincial policies to explain provincial differences in poverty conditions; although we may quibble that the county is the more appropriate unit of

\footnotetext{
${ }^{69}$ Geographers have produced a large literature on the concept of scale. This literature, which explores the relationship between social and economic processes and dynamic geographic scales, could be useful for political scientists attempting to understand the centralization and decentralization of various political processes. See Brenner 2004, Cartier 2005.

70 "Central-local relations" serves as an important condition in both accounts, but both authors could be much clearer about how they expect provincial status to affect patterns of investment and intervention. In a very real sense, Xi' an and Shanghai or Shanghai and Changchun are not comparable units, a point to which I will return in Section VI.

${ }^{71}$ Oi 1999.
} 
analysis at which to analyze rural poverty, Donaldson's research design is very clear. ${ }^{72}$ Hurst, in this book and elsewhere, is more attentive to the comparison of cities. ${ }^{73} \mathrm{He}$ chose as field sites cities within the regions he identified as representative of the "dimensions of contemporary regional political economy:" "sectoral distribution of SOEs, timing and manner of industrialization, location of SOEs, relative presence of market activity and commercial centers, transportation infrastructure, and historical relationship with the central government" (p. 31). Though, as noted above, Hurst certainly runs the risk of bringing too many independent variables to bear on the outcomes he aims to explain, his identification of the units of analysis is clear enough to permit the some generalization. By this I mean that we would be able to take any city in China and generate some expectations about labor politics there based on Hurst's formulation.

Breznitz \& Murphree are perhaps the least precise in characterizing the unit of analysis. They examine what they call "regional innovation systems" in the information technology industry, comparing Beijing ("a city of start-ups"), Shanghai ("a large-scale industrial structure"), and the Pearl River Delta (a "resilient" industrial structure built "seemingly out of nothing"). Beijing and Shanghai are, of course, centrally administered cities of 20 and 23 million respectively, and the PRD is an urban agglomeration encompassing eight Mainland cities and over 120 million people. ${ }^{75}$ Breznitz \& Murphree make a strong case that these "regions" differ in their innovation systems and patterns of state-industry relations, but give no guidance as to what other systems of innovation or patterns we may or may not expect in other areas or why. It is not clear if the model they

\footnotetext{
${ }^{72}$ Many scholars, as well as the Chinese state, focus on poverty at the county level. Shue and Wong 2007.

${ }^{73}$ Hurst 2006.

${ }^{75}$ Figures based on preliminary estimates from 2010 Census results. National Bureau of Statistics.
} 
elucidate applies only to the cases they discuss, or rather if the cases are representative of regional types.

In addition to a more precise elucidation of scale, the "old regionalists" share a conceptual clarity and efforts at abstraction that should serve as models of theory building for the new regionalists. Skinner, Locke, and Herrigel elucidate ways in which the regions they identify remain resilient in the face of economic, political, and social change. These authors were not characterizing regional differences with regard to a single outcome, such as urbanization or sectoral investment, but instead endeavored to show how regional differences reproduce themselves across sectors and industries and with regard to a number of social and political processes. To do this, both Locke and Herrigel develop concepts that enable them to abstract out of their specific field sites and identify characteristics of "economic orders" that could then be identified elsewhere. Locke does this by elaborating three "ideal typical" patterns of economic organization: polycentric, polarized, and hierarchical systems, which differ in "the structure of intergroup relations, patterns of associationalism, and linkages to central policymakers. ${ }^{, 76}$ Herrigel identifies two "industrial orders." The "decentralized order" is characterized by a predominance of small and medium enterprises and a "system of governance mechanisms that stimulate innovation, socialize risk, and foster adjustment...in ways that do not resemble the governing principles of either markets or hierarchies." ${ }^{, 77}$ The autarkic order, on the other hand, fits the more traditional view of German industrialization: "dominated by very large scale, vertically integrated enterprises, with close ties to universal banks." ${ }^{, 78}$

\footnotetext{
${ }^{76}$ Locke 1995, 25.

${ }^{77}$ Herrigel 1996, 1 .

${ }^{78}$ Herrigel 1996, 2.
} 
Only Donaldson's and Thun's books involve this kind of effort at conceptual innovation. Donaldson characterizes Yunnan province's approach to growth and poverty as emblematic of a "developmental state:" "The Yunnan government approached development primarily by altering the market, investing resources in key industries, focusing on large-scale industrialization, and attempting to shift labor from agriculture to industry" (p. 153). In contrast, he characterizes Guizhou as the "micro-oriented state:" focusing on small-scale development strategies, the Guizhou effort sought specifically to "reduce poverty by increasing accessible opportunities for poor people" (p. 163). Thun situates his cases along two dimensions: bureaucratic organization (fragmented or unified) and the form of inter-firm relations (hierarchical or market coordination). From here he determines that Shanghai, enjoying hierarchical coordination and a unified bureaucracy, is a local developmental state; Changchun and Wuhan have hierarchical coordination but fragmented bureaucracies, and are therefore "firm-dominated localities;" and Guangzhou and Beijing both have market coordination and fragmented bureaucracies, a combination which produces "laissez-faire" local governments (pp. 2627). Regrettably, the other books do not contain systematic efforts to abstract out of the cases at hand. To be fair, the empirical richness contained in each case discussion might trade off with the authors' abilities to generalize outside their cases. Nonetheless, some characterizations of regional variation read more like descriptions of idiosyncratic cases rather than the identification of variables or mechanisms that can be found to operate similarly in other cases. The fact that Beijing, Guangzhou, and Shanghai constitute central cases in three of these books also compromises the authors' abilities to generalize 
or identify conceptual types, since these may be "some of China's most atypical cities" (pp. 464-5). ${ }^{82}$

Whether from a constructivist or structural standpoint, the new regionalists share with the old the core contentions that Chinese regions experience endogenous transformation and that not only economic outcomes vary by region, but the very rules of decision-making vary regionally as well. These two contentions, read alongside one another, implore us to take seriously heterogeneity of units in comparing across regions in China and caution us against assuming that changes in central policy or incentives will affect all areas in similar ways. The presence and reproduction of these different economic orders, however, begs the question of their genesis.

\section{Whither Socialist Legacies?}

If the authors of these books disagree on the causal mechanisms that account for regional differences, most are in agreement regarding the origins of those mechanisms. With the exception of Donaldson, who chooses cases so as to control for socialist legacies, all of these authors emphasize the ways in which institutions, ideas, and social relations at the subnational level are under the shadow of the Maoist period. No one with basic knowledge of the Maoist period would claim that socialist legacies are immaterial to the organization of the economy in contemporary China. Yet, deploying "socialist legacies" as the key explanatory variable for regional economic diversity seems unsatisfying or at least incomplete for several reasons.

\footnotetext{
${ }^{82}$ Though clearly Segal, Thun, and Breznitz \& Murphree were writing books about specific industries, and therefore leaving these cities out would have omitted the key loci of the phenomena they wanted to explain.
} 
First, some presumed "socialist legacies," upon some consideration, seem to themselves be products of pre-socialist forms of organization. Consider Susan Whiting's treatment of Maoist-era rural industrialization and its effects on forms of property rights after reforms. She finds that, ironically given the CCP's emphasis on "self-reliant" rural industry during the Great Leap Forward, the Commune and Brigade Enterprises (CBEs) that were most "self-reliant" were attacked as capitalist, and others benefitted from substantial state support. In the case in which enterprises were attacked or denied state support-Yueqing County in Zhejiang Province-Whiting finds a predominance of private ownership as a result of a weak collective industrial endowment at the outset of reforms. In the cases in which Maoist era enterprises received the most central supportSongjiang County outside Shanghai and Wuxi County in Jiangsu Province-rural enterprises are predominantly publicly owned (pp. 40-71). Whiting's finding that many CBEs enjoyed central state support was in itself a major contribution to understandings of rural industrialization under Mao and after his death, but the Yueqing story begs the question: why, during the Maoist era, were Yueqing's CBEs and those in Songjiang and Wuxi more often collective? Given, moreover, that Zhejiang Province receives significant praise for its famed entrepreneurship and dynamic private economy ${ }^{84}$ one wonders if something runs deeper in the region's economic culture, diaspora connections, or pattern of economic organization that explains the rise of private enterprises before, during, and after the Maoist period.

Other times, these "legacies" seem more likely to be products of post-1978 changes. Take, for example, Thun's discussion of institutional heritage in Shanghai. In arguing that institutional legacies matter long after "differences have been smoothed

\footnotetext{
${ }^{84}$ Liu 1992, Parris 1993.
} 
over," Thun relies on the key contention of the historical institutionalist school of thought that "institutions are shaped over time and change only slowly" (p. 36). ${ }^{85} \mathrm{He}$ is worth quoting at length:

The path-dependent nature of institutional change is not new, but it has important implications for development policy. If a region has an institutional advantage (or disadvantage) it is the product of decades of political and economic history, and in the absence of strong external pressure it is unlikely that policymakers will be able to easily change this advantage, either to conform to the whims of policy fashions, or to satisfy the needs of an evolving economic sector. (p. 37)

Yet, the story he tells about local state "developmentalism" in Shanghai does not accord with this account of institutional stasis. On the contrary, he describes how the municipal government "fine-tuned the bureaucratic structure so as to be able to effectively coordinate and monitor developmental efforts" (p. 107), including a reorganization of the bureaucracy charged automobile industry oversight and the establishment of new offices in charge of localizing supply (pp. 107-116). This seemingly rapid institutional innovation suggests that some municipal governments are indeed capable of overhauling existing institutions to pursue growth in certain sectors, albeit conforming to long established patterns of state investment. ${ }^{89}$

This does not mean, of course, that socialist legacies cannot determine patterns of state intervention in the economy or even change in economic organization. Rather, precise theoretical propositions involving the enduring power of socialist legacies would require clear articulation of the mechanisms through which legacies from the socialist period - be they institutional or ideational - are reproduced. All of these books include

\footnotetext{
${ }^{85}$ Thun p. 36. See Pierson 2000, Hall and Taylor 1996, Pierson 2004, Steinmo, Thelen and Longstreth 1992.

${ }^{89}$ To be fair, "socialist legacy" is hardly the only variable that he uses to explain different municipal models of automobile industry promotion. He also emphasizes a locale's relationship with the central government in Beijing, and in particular how institutional legacies evolve given that relationship.
} 
examples of what could be "feedback mechanisms" or increasing returns: for example, Hurst's analysis of "mobilizing structures" foregrounds housing compounds and apartment blocks established during the state socialist period as an ecological asset in organizing worker contention (pp. 108-132). Another tack would be clearer specification of how institutional change actually can serve to reify original differences among regions. For example, the literature on transitions in the post-communist world has for decades emphasized how communist (and pre-communist) legacies may have influenced levels of democratic consolidation across East and Central Europe. Yet scholars of this region have been involved in extensive debates about how to characterize and theorize the causal effects of "legacies," pre- and post-communist. ${ }^{91}$ Of course, the communist experience (and the transition from communism) was more varied among the countries of the Soviet bloc than within China, but China scholars would do well to specify and theorize the causal power of Chinese socialist legacies with the same care.

Perhaps ironically, it is Whiting who both offers the strongest explanation of the reproduction of socialist legacies as well as the most space for those legacies to be overridden in a dynamic process of institutional change. The conclusion to her book discusses how much of rural China converged on the privatization of rural industrial enterprises in the late 1990s as the central government in Beijing changed the rules of the fiscal system that permitted local divergence: "when substantial change occurs in the larger institutional environment, dramatic and seemingly disjunct change can occur in the paths of local institutional development" (p. 267). What would it take to change these legacies in institutional, ideational, and socio-political models of regional variation in China? Certainly, these books are convincing that there is continuity in regional

\footnotetext{
${ }^{91}$ See Bunce 2003, Bunce 2005, Darden and Grzymala-Busse 2006, Wittenberg 2006.
} 
approaches to development, across time and across sectors. Breznitz \& Murphree characterize regional approaches to the IT sector in largely similar ways to Segal, who wrote eight years earlier.

Taking inspiration from Whiting's attention to institutional change, the field of political economy in China might also turn its attention to the ways in which changes to the post-Mao administrative hierarchy has made the rules of economic organization irrevocably different across different subnational regions in China. Regardless of how we conceptualize socialist legacies, we can agree that the politics of growth, investment, and state-society relations are very different in places that opened early and widely to market reforms and global capital. Localities in central and western China, in this view, are not simply playing "catch-up" to their eastern counterparts, but—for reasons that have nothing to do with the socialist past and everything to do with the course of reformsthey have no eastern counterparts. Subnational localities may belong to "regions" that are not spatial representations, but rather categories of cities according to maneuvering ability vis-à-vis the central government. ${ }^{93}$

The books discussed in this essay feature many references to how the post-1978 reforms have affected regions differently, for example in central-local relations, timing and sequencing of reform, and degree of foreign opening. Yet these reform era factors are neglected relative to the attention afforded to socialist legacies. As research on political economies in China achieves greater granularity and academics broaden their field sites, it is worth considering - as systematically as possible - whether and how the outcomes

\footnotetext{
${ }^{93}$ Geographers have long been attentive to how regions may be deployed as a "subunit of national space that may be divided into a variety of abstract divisions depending on the criteria used," i.e. not really contiguous spatial areas in a literal sense. Friedmann and Weaver 1979, Yang 1997, 4.
} 
we aim to explain are linked to variables or processes that emerged from the period of state socialism or rather from eras before or after Mao.

Though I have emphasized the benefits of theorizing endogenous local change in China, a final admonition concerns the risks of taking "endogenous change" too far. In an effort to uncover subnational variation and reject "whole nation bias," scholars should also be wary of what some call "methodological localism:" an excessive focus on local institutions or social processes while neglecting the supralocal power relations in which localities are embedded. ${ }^{94}$ This could be especially injurious in the Chinese case, since perhaps the most intriguing, and least understood, element of China's political system writ large is the interplay between political power at different scales. One of the most controversial pieces of scholarship on the origins of the Chinese reforms-Lynn White's Unstately Power (in two volumes, 1998) —attempts to study exactly this. White bristles at the idea that the reforms began at the initiation of central authorities in 1978, and instead meticulously tracks how local political networks in the city of Shanghai embarked on reforms in policy areas ranging from literature to social welfare provision well before those reforms had occurred to actors at the center. He argues that, in fact, national reforms were in many ways brought about by the actions of local networks: "The cumulative influence of countermeasures from many localities, acting in parallel, often became national policy not fully intended by the government. ${ }^{" 95}$ The argument was controversial because determining the directionality of policy in China is notoriously difficult, yet these interactions between local and central networks are surely at the heart of major policy changes.

\footnotetext{
${ }^{94}$ See Brenner 2009.

${ }^{95}$ White 1998, Vol. 1, 8. See Kelliher 1992 and Zhou 1996 for similar arguments about the rural reforms.
} 
While we may be unsure of what outcomes are products of local insistence, central direction, or, likely, some interaction between different scales, we may be certain about what Sebasian Heilmann has called the "shadow of hierarchy:" that the central government in Beijing remains at the apex of the Chinese political hierarchy, and various local policies and programs must enjoy the center's support or total neglect in order to survive. ${ }^{96}$ This lurking power of the center is certainly not dismissed in the books reviewed here, but this emerging research agenda on local change enjoys an opportunity to bring hierarchy out of the "shadows" and into the foreground of theoretical development in Chinese politics. This kind of multi-level theorizing will only be possible by taking seriously local heterogeneity but also the central power dynamics that promote or inhibit it.

\section{Conclusion}

In recent years, and especially since the financial crisis of 2008 and subsequent debt crises in Europe and the United States, many have celebrated the so-called "Beijing Consensus" as a Chinese alternative to the "western" path to growth. While some debate the viability of a proposed Chinese model, ${ }^{97}$ the scholars whose work I discussed in this essay reject the idea that a country as large and as diverse as China could possibly support one single model of development. Indeed, this scholarship, which goes beyond recognizing subnational variation and instead intends to systematically probe its origins, marks a certain maturation of theory development in Chinese political economy.

\footnotetext{
${ }^{96}$ Heilmann 2009.

${ }^{97}$ See Huang 2011.
} 
Richard Locke's seminal work on regional variation in the Italian economy was initially motivated by an attempt to account for the simultaneous success and failure of national efforts at reforms. The period of his study (1970-1990) was a tumultuous one as nation states attempted to reform internally to better adjust to changes in the international economy. Recent shocks to the international economy and changes in policy in Beijing indicate that reforms of a similar scale are on the horizon in China. The proponents of the "new regionalism" teach us that possible reforms of everything from the rural and urban land tenure systems to municipal government financing to rural modernization to internal migration reform will play out very differently sub-nationally. But acknowledging the fact of regional variation itself no longer constitutes an advance of knowledge about the workings of political economy in China. Instead of simply describing the ways in which economic and political outcomes of interest vary sub-nationally, China scholars should build on the solid foundation of work discussed here to engage with what institutional, ideational, or socio-historical factors bear on differences among comparable subnational units. 
2001. China: Overcoming Rural Poverty. Washington, D.C.: World Bank. Abdelal, Rawi. 2001. National Purpose in the World Economy: Post-Soviet States in Comparative Perspective. Ithaca, N.Y.: Cornell University Press.

Abdelal, Rawi, Mark Blyth and Craig Parsons. 2010. Constructing the International Economy. Ithaca, N.Y.: Cornell University Press.

Brenner, Neil. 2004. New State Spaces: Urban Governance and the Rescaling of Statehood. Oxford, UK and New York, N.Y.: Oxford University Press.

---. 2009. "Is There a Politics of 'Urban' Development? Reflections on the Us Case." In Richardson Dilworth, ed., The City in American Political Development. New York, N.Y. and London, UK: Routledge.

Breznitz, Dan and Michael Murphree. 2011. Run of the Red Queen: Government, Innovation, Globalization, and Economic Growth in China. New Haven C.T.: Yale University Press.

Bunce, Valerie. 2003. "Rethinking Recent Democratization: Lessons from the Postcommunist Experience." World Politics 55, no. 2: 167-192.

---. 2005. "The National Idea: Imperial Legacies and Post-Communist Pathways in Eastern Europe." East European Politics \& Societies 19, no. 3 (Summer): 406-442. Cai, Hongbin and Daniel Treisman. 2006. "Did Government Decentralization Cause China's Economic Miracle?" World Politics 58, no. 4: 505-535.

Cartier, C. 2002. "Origins and Evolution of a Geographical Idea: The Macroregion in China." Modern China 28, no. 1: 79-112.

Cartier, Carolyn. 2005. "City-Space: Scale Relations and China's Spatial Administrative Hierarchy." In Laurence Ma and Wu Fulong, eds., Restructuring the Chinese City: Changing Society, Economy and Space. London, UK and New York, N.Y.: Routledge. Chan, Anita, Richard Madsen, Jonathan Unger and University of California Berkeley. Center for Chinese Studies. 1984. Chen Village: The Recent History of a Peasant Community in Mao's China. Berkeley, C.A.: University of California Press. Chŏng, Chae-ho. 2000. Central Control and Local Discretion in China : Leadership and Implementation During Post-Mao Decollectivization. Oxford, UK and New York, N.Y.: Oxford University Press.

Clarke, Donald. 2003. "Economic Development and the Rights Hypothesis: The China Problem." American Journal of Comparative Law 51, no. 1: 89-111.

Cornelius, Wayne A., Todd A. Eisenstadt and Jane Hindley. 1999. Subnational Politics and Democratization in Mexico. La Jolla, C.A.: Center for U.S.-Mexican Studies, University of California, San Diego.

Darden, Keith and Anna Grzymala-Busse. 2006. "The Great Divide: Literacy, Nationalism, and the Communist Collapse." World Politics 59, no. 1: 83-115. Donaldson, John A. 2009. "Why Do Similar Areas Adopt Different Developmental Strategies? A Study of Two Puzzling Chinese Provinces." Journal of Contemporary China 18, no. 60: 421-444.

Edin, Maria. 2003. "Remaking the Communist Party-State: The Cadre Responsibility System at the Local Level in China." China: An International Journal 1, no. 1: 1-15. Fan, C. Cindy. 1995. "Of Belts and Ladders: State Policy and Uneven Regional Development in Post- Mao China." Annals of the Association of American Geographers 85, no. 3: 421-449. 
---. 1997. "Uneven Development and Beyond: Regional Development Theory in PostMao China." International Journal of Urban and Regional Research 21, no. 4: 620-639. Fan, Shenggen, S. M. Ravi Kanbur and Xiaobo Zhang. 2009. Regional Inequality in China: Trends, Explanations and Policy Responses. London, UK: Rouledge. Friedmann, John and Clyde Weaver. 1979. Territory and Function : The Evolution of Regional Planning. London, UK: E. Arnold.

Garrett, Geoffrey and Peter Lange. 1986. "Performance in a Hostile World: Economic Growth in Capitalist Democracies, 1974-1982." World Politics 38, no. 4: 517-545. Gibson, Edward L. 2004. Federalism and Democracy in Latin America. Baltimore, M.D.: Johns Hopkins University Press.

Hagopian, Frances. 1996. Traditional Politics and Regime Change in Brazil. Cambridge, UK: Cambridge University Press.

Hall, Peter A. 1986. Governing the Economy: The Politics of State Intervention in Britain and France. New York, N.Y.: Oxford University Press.

Hall, Peter A. and Rosemary C. R. Taylor. 1996. "Political Science and the Three New Institutionalisms." Political Studies 44, no. 5: 936-957.

Heilmann, Sebastian. 2008a. "From Local Experiments to National Policy: The Origins of China's Distinctive Policy Process." The China Journal, no. 59: 1-30.

---. 2008b. "Policy Experimentation in China's Economic Rise." Studies in Comparative International Development 43, no. 1 (Spring): 1-26.

---. 2009. "Maximum Tinkering under Uncertainty: Unorthodox Lessons from China." Modern China 35, no. 4 (July 1, 2009): 450-462.

Heilmann, Sebastian and Elizabeth J. Perry. 2011. Mao's Invisible Hand: The Political Foundations of Adaptive Governance in China. Cambridge, M.A.: Harvard University Asia Center :Distributed by Harvard University Press.

Herrera, Yoshiko M. 2005. Imagined Economies: The Sources of Russian Regionalism. Cambridge: Cambridge University Press.

Herrigel, Gary. 1996. Industrial Constructions: The Sources of German Industrial Power. Cambridge, UK: Cambridge University Press.

Huang, Yasheng. 2011. "Rethinking the Beijing Consensus." Asia Policy, no. 11

(January): 1-26.

Hurst, W. 2006. "The City as the Focus: The Analysis of Contemporary Chinese Urban Politics." China Information 20, no. 3: 457-479.

Hurst, William. 2009. The Chinese Worker after Socialism. Cambridge, UK: Cambridge University Press.

Kalyvas, Stathis N. 2006. The Logic of Violence in Civil War. Cambridge, UK:

Cambridge University Press.

Katzenstein, Peter J. 1978. Between Power and Plenty: Foreign Economic Policies of Advanced Industrial States. Madison, W.I.: University of Wisconsin Press.

Kelliher, Daniel Roy. 1992. Peasant Power in China: The Era of Rural Reform, 19791989. New Haven, C.T.: Yale University Press.

Landry, Pierre F. 2008. Decentralized Authoritarianism in China: The Communist

Party's Control of Local Elites in the Post-Mao Era. New York, N.Y.: Cambridge University Press. 
Lau, Lawrence J, Yingyi Qian and Gerard Roland. 2000. "Reform without Losers: An Interpretation of China's Dual - Track Approach to Transition." Journal of Political Economy 108, no. 1: 120-143.

Lee, Ching Kwan. 2007. Against the Law: Labor Protests in China's Rustbelt and Sunbelt. Berkeley, C.A.: University of California Press.

Lipset, Seymour Martin and Stein Rokkan. 1967. Party Systems and Voter Alignments: Cross-National Perspectives. New York, N.Y.: Free Press.

Liu, Alan P. L. 1992. "The "Wenzhou Model" of Development and China's

Modernization." Asian Survey 32, no. 8: 696-711.

Locke, Richard M. 1995. Remaking the Italian Economy. Ithaca, N.Y.: Cornell

University Press.

Madsen, Richard and University of California Berkeley. Center for Chinese Studies.

1984. Morality and Power in a Chinese Village. Berkeley, C.A.: University of California Press.

Montinola, Gabriella, Yingyi Qian and Barry R. Weingast. 1995. "Federalism, Chinese Style: The Political Basis for Economic Success in China." World Politics 48, no. 1: 5081 .

Moore, Barrington. 1966. Social Origins of Dictatorship and Democracy; Lord and Peasant in the Making of the Modern World. Boston, M.A.: Beacon Press.

Naughton, Barry. 1995. Growing out of the Plan: Chinese Economic Reform, 1978-1993. New York, N.Y.: Cambridge University Press.

Oi, Jean Chun. 1999. Rural China Takes Off: Institutional Foundations of Economic Reform. Berkeley, C.A.: University of California Press.

Oi, Jean Chun and Andrew G. Walder. 1999. Property Rights and Economic Reform in China. Stanford, C.A.: Stanford University Press.

Parris, Kristen. 1993. "Local Initiative and National Reform: The Wenzhou Model of Development." The China Quarterly, no. 134: 242-263.

Perry, Elizabeth J. 1994. "Trends in the Study of Chinese Politics: State-Society Relations." China Quarterly, no. 139: 704.

Pierson, Paul. 2000. "Increasing Returns, Path Dependence, and the Study of Politics." The American Political Science Review 94, no. 2: 251-267.

---. 2004. Politics in Time: History, Institutions, and Social Analysis. Princeton, N.J.:

Princeton University Press.

PRC, 2001, The Development-Oriented Poverty Reduction Porgram for Rural China, (State Council, People's Republic of China, Beijing).

Putnam, Robert D., Robert Leonardi and Raffaella Nanetti. 1993. Making Democracy Work: Civic Traditions in Modern Italy. Princeton, N.J.: Princeton University Press. Rokkan, Stein. 1970. Citizens, Elections, Parties; Approaches to the Comparative Study of the Processes of Development. New York, N.Y.: McKay.

Segal, Adam. 2003. Digital Dragon: High-Technology Enterprises in China. Ithaca, N.Y.: Cornell University Press.

Segal, Adam and Eric Thun. 2001. "Thinking Globally, Acting Locally: Local

Governments, Industrial Sectors, and Development in China." Politics \& Society 29, no. 4 (December): 557-588.

Shih, Victor C. 2008. Factions and Finance in China: Elite Conflict and Inflation.

Cambridge, UK: Cambridge University Press. 
Shirk, Susan L. 1993. The Political Logic of Economic Reform in China. Berkeley, C.A.: University of California Press.

Shue, Vivienne. 1988. The Reach of the State: Sketches of the Chinese Body Politic.

Stanford, C.A.: Stanford University Press.

Shue, Vivienne and Christine Wong. 2007. Paying for Progress in China: Public

Finance, Human Welfare and Changing Patterns of Inequality. London, UK: Routledge.

Skinner, G. William. 1985. "Presidential Address: The Structure of Chinese History." The Journal of Asian Studies 44, no. 2: 271-292.

Skinner, G. William and Hugh D. R. Baker. 1977. The City in Late Imperial China.

Stanford, C.A.: Stanford University Press.

Snyder, Richard. 2001. "Scaling Down: The Subnational Comparative Method." Studies

in Comparative International Development 36, no. 1 (Spring): 93.

Steinfeld, Edward S. 1998. Forging Reform in China: The Fate of State-Owned Industry. Cambridge, UK and New York, N.Y.: Cambridge University Press.

Steinmo, Sven, Kathleen Ann Thelen and Frank Longstreth. 1992. Structuring Politics:

Historical Institutionalism in Comparative Analysis. Cambridge, UK: Cambridge

University Press.

Thelen, Kathleen. 2003. "How Institutions Evolve: Insights from Comparative Historical

Analysis." In, Comparative Historical Analysis in the Social Sciences. Cambridge

University Press.

Thun, Eric. 2006. Changing Lanes in China: Foreign Direct Investment, Local

Governments, and Auto Sector Development. Cambridge, UK and New York, N.Y.:

Cambridge University Press.

Tsai, Kellee S. 2002. Back-Alley Banking: Private Entrepreneurs in China. Ithaca, N.Y.: Cornell University Press.

Tsai, Lily L. 2007. Accountability without Democracy: Solidary Groups and Public

Goods Provision in Rural China. Cambridge, UK: Cambridge University Press.

Varshney, Ashutosh. 2002. Ethnic Conflict and Civic Life: Hindus and Muslims in India. New Haven, C.T.: Yale University Press.

Walder, Andrew G. 1986. Communist Neo-Traditionalism: Work and Authority in

Chinese Industry. Berkeley, C.A.: University of California Press.

Wang, Shaoguang and Angang Hu. 1999. The Political Economy of Uneven

Development: The Case of China. Armonk, NY: M.E. Sharpe.

White, Lynn T. III. 1998. Unstately Power. Vol. 1 The Local Causes of China's

Economic Reforms. Vol. 2. Local Causes of China's Intellectual, Legal, and

Governmental Reforms. Armonk, N.Y.: M.E. Sharpe.

Wilkinson, Steven. 2006. Votes and Violence: Electoral Competition and Ethnic Riots in India. Cambridge, UK: Cambridge University Press.

Wittenberg, Jason. 2006. Crucibles of Political Loyalty: Church Institutions and

Electoral Continuity in Hungary. New York, N.Y.: Cambridge University Press.

Wong, Christine. 1997. Financing Local Government in the People's Republic of China. Hong Kong: Published for the Asian Development Bank by Oxford University Press.

Yang, Dali L. 1997. Beyond Beijing: Liberalization and the Regions in China. London, UK and New York, N.Y.: Routledge.

Zhou, Kate Xiao. 1996. How the Farmers Changed China: Power of the People. Boulder, C.O.: Westview Press. 
Ziblatt, Daniel. 2006. Structuring the State: The Formation of Italy and Germany and the Puzzle of Federalism. Princeton, N.J.: Princeton University Press.

Ziblatt, Daniel and Lily L. Tsai. 2009. "The Rise of Subnational and Multilevel

Comparative Politics." Working Paper.

Zysman, John. 1983. Governments, Markets, and Growth: Financial Systems and the Politics of Industrial Change. Ithaca, N.Y.: Cornell University Press. 